\title{
Organic matter decomposition by fungi in a Mediterranean forested stream : contribution of streambed substrata
}

\author{
J. Artigas*, A.M. Romaní, S. Sabater
}

Aquatic Ecology Institute \& Dept. Environmental Sciences, University of Girona, Campus Montilivi, E-17071, Girona, Spain.

\begin{abstract}
Aquatic microfungi play a fundamental role in organic matter decomposition in fluvial ecosystems. These micro-organisms degrade leaf recalcitrant compounds like lignin, thereby enhancing the utilization of organic material by the microbial community. The main input of allochthonous organic matter in Mediterranean streams occurs during the autumn. In-stream breakdown processes can be affected by high physical abrasion during flooding but changes in stream water chemistry may also affect decomposition enzymatic activities of stream microorganisms. We measured two ligninolytic activities (phenol oxidase and peroxidase) and a cellulolytic activity (cellobiohydrolase) in leaves, branches, sand and gravel substrata in a reach of a Mediterranean stream. Highest ligninolytic activities were measured in biofilm developed on inorganic substrata (sand and gravel) where also accumulated the highest fungal biomass (ranging from $3.3 \times 10^{-4}$ to $7.22 \mathrm{mg}$ Ergosterol gAFDM $^{-1}$ ) especially in sand substrata. Conversely, cellulolytic activities were significantly higher in biofilm on organic substrata (leaves and branches). Physical and chemical factors, such as discharge and stream water nutrient concentration (Dissolved Inorganic Nitrogen) were affecting enzymatic activities, particularly enhancing the phenol oxidase. Moreover, the chemical composition of the available OM (high cellulose in leaves, high lignin in detritic material) strongly influenced the decomposition activity in each biofilm. A precise description and quantification of the benthic substrata was used to obtain enzymatic activity values in terms of stream reach. Those results showed a temporal pattern in the decomposition activities in the reach, beginning with the decomposition of cellulose (October) followed by lignin compounds (November and December).
\end{abstract}

Keywords : Aquatic microfungi, decomposition, enzymatic activities, organic matter, streambed substrata.

\section{Introduction}

In forested streams where light is a limiting factor for primary production, energy sources are mainly allochthonous (leaf litter), the metabolic processes being typically heterotrophic (Fisher \& Likens 1973, Minshall et al. 1983). In Mediterranean systems, the greatest input of plant material occurs in autumn, thereby providing the potential for decomposition processes. The initial breakdown of leaves in the stream is mainly carried out by aquatic hyphomycetes (Suberkropp \& Klug 1976, Findlay \& Arsuffi 1989, Gessner \& Chauvet 1994, Mathuriau \& Chauvet 2002), while the contribution of bacteria is lower (Hieber \& Gessner 2002). This group of fungi is crucial in decomposition process as it breaks down lignified carbohydrates,

\footnotetext{
* Corresponding author :

E-mail: u1022644@correu.udg.es
}

which constitute a natural protection of polysaccharide components against enzymatic attack (Griffin 1994). After cellulose, lignin is the most abundant form of aromatic carbon in the world. Lignin degradation does not provide a primary source of carbon and energy for fungal growth, but decay process and utilization of carbohydrates for fungal growth can occur only with the coordinate degradation of this carbon (Griffin 1994).

Decomposition process may be related to variations in inorganic nutrient availability. It has been observed that the addition of nitrogen $(\mathrm{N})$ increases cellulase activity and decreases lignin-degrading phenol oxidase activity (Carreiro et al. 2000). Moreover, the chemical nature of streambed substrata, such as the tannin content or the physical properties of leaves (high waxy cuticles), has been proposed as a major determinant of breakdown rate (Barlöcher et al. 1995). Sinsabaugh et al. (1992) determined that phenol oxidase activity was substrate-related but not site-related. 
Studies on the decomposition of organic matter (OM) have mainly focused on organic substrata (leaves and branches) (e. g. Gessner \& Chauvet 1994, Pozo et al. 1998, Diez et al. 2002). However, other riverbed substrata receive significant accumulations of allocthonous material during autumn. The accumulation of decomposing material occurs in pools or littoral zones and in debris dam. Specifically, sand sediments accumulate large amounts of detritic material.

Here we evaluated the role of fungi on the decomposition of OM during autumn in a forested Mediterranean stream, and studied the way in which their role was shared between the distinct streambed substrata (leaves, sand, gravel and branches) where substantial OM decomposition may occur. For this purpose, we measured ligninolytic and cellulolytic enzymatic activities on gravel and sand, on the leaves of several species [Alnus glutinosa (Gaertn.), Populus nigra (L.) and Platanus x hispanica (Mill. ex Münch.)] and on branches, to determine the most active site of OM decomposition among the substrata types. We studied the relationships between enzymatic activities and fungal biomass (ergosterol content) of biofilms in each substrata, but also, with the physico-chemical parameters of stream water to establish which variables were controlling the decomposition process in the different riverbed substrata.

\section{Study site}

Fuirosos is a third-order stream that drains a forested catchment area of $10.9 \mathrm{Km}^{2}$ close to the Mediterranean Sea (NE Spain). The climate is typically Mediterranean, with temperatures ranging from $3^{\circ} \mathrm{C}$ in January to $24^{\circ} \mathrm{C}$ in August. Precipitation is distributed irregularly, autumn and spring having most rainfall while summer storms occur only occasionally. For this reason, flow velocity usually ceases from July to August until September to October. Mean flow is about 5-20 $\mathrm{L} / \mathrm{s}$. Litter fall peaks in autumn. Flooding in autumn coincides with the increase in water nutrient content as a result of soil leachates (Bernal et al. 2002) and leaves input during the fall season. We studied a stream reach of $33 \mathrm{~m}$ in length and 3 to $5 \mathrm{~m}$ wide. The stream channel is characterised by step-pool morphology with large cobbles and boulders. Most of plant material input into the stream was leaf litter from the plane tree (Platanus $\mathrm{x}$ hispanica), alder (Alnus glutinosa), and poplar (Populus nigra). The accumulation of wood $<2.5 \mathrm{~cm}$ diameter was low (Sabater et al. 2001).

\section{Materials and methods}

\section{Sampling}

Sampling of leaves, branches, sand and gravel was performed at fortnight intervals from October 2002 to
January 2003 , for a total of seven sampling dates. We analysed eleven transects (3 $\mathrm{m}$ apart) in the reach studied and identified the relative cover $(\%)$ of each streambed substrata every $20 \mathrm{~cm}$. The distinct substrata considered were: fresh leaves, decaying leaves, branches, sand-gravel (which were classified together because of the high mixture and compaction of grains) and rock. Accumulation of detritic material has also been visually quantified as the fine and coarse organic material covering the streambed. Current velocities and water depth were also measured at each sampling point.

Benthic substrata were randomly collected following a stratified sampling design. In total 9 substrata types (defined as follows) were sampled in 7 sampling dates. Leaves of three species were collected : Alnus glutinosa, Platanus $x$ hispanica, and Populus nigra, considering separately leaves just fallen into the stream (fresh leaves) and those being already immersed (decaying leaves). Fresh and decaying leaves were separated on the basis of the colour and consistency of the material. For enzymatic analysis, a metal borer was used to obtain discs (1.3 cm diameter) from the collected leaves. Sampled branches were 0.5 to $1.5 \mathrm{~cm}$ in diameter and $1.5 \mathrm{~cm}$ long, and were obtained by cutting long branches stored in the stream. Sand substrata was sampled by coring an area of aprox. $2 \mathrm{~cm}$ depth with a plastic container. Sand samples for enzymatic activities were later collected from the container with an untapped syringe (ca. $1 \mathrm{ml}$ sand volume per sample). Gravel samples were taken directly from the streambed as individual grains of 1.5 to $2 \mathrm{~cm}$ diameter. Sand and gravel samples included the sand grains, the biofilm which colonised them and the detritic material which was accumulated.

Analysis for enzyme activity was carried out in samples collected separately, placed in glass vials with stream water and preserved at $4^{\circ} \mathrm{C}$ until analysis. Samples for ergosterol analysis were placed in plastic vials and frozen $\left(-20^{\circ} \mathrm{C}\right)$ until analysis.

\section{Physico-chemical parameters}

At each sampling date, temperature, light, conductivity, $\mathrm{pH}$, and dissolved oxygen were measured in the field. Incident light was measured with a LiCor quantum sensor (Li-192SB). Filtered (precombusted Whatman $\mathrm{GF} / \mathrm{F}$ filters) water samples (3 replicates) were used to analyze inorganic nutrients (ammonium, nitrate, nitrite and soluble reactive phosphorus) (APHA 1989). Dissolved organic carbon (DOC) and dissolved inorganic carbon (DIC) were measured through a Total Organic Carbon analyzer (TOC-5000, Shimadzu).

\section{Enzyme assays}

Enzyme assays of the solid samples (leaves, branches, sand and gravel) were conducted under substrate saturating conditions (determined from satura- 
tion curves performed previously). Enzyme incubations (4 replicates plus controls) were done in the dark in a shaking bath set at stream water temperature.

Each substratum was assayed for three extracellular enzymes involved in the degradation of holocellulose and polyphenolic substances: cellobiohydrolase (CBH, EC 3.2.1.91), phenol oxydase (PO, EC 1.10.3.2 $\&$ 1.14.18.1) and peroxidase (P, EC 1.11.1.7). Extracellular $\mathrm{CBH}$ activity was measured spectrofluorometrically using a MUF (methylumbelliferyl) substrate analogue (MUF-cellobioside) at $1.5 \mathrm{mM}$. The tubes were capped and incubated for 2 hours. After the addition of $0.05 \mathrm{~mol} / \mathrm{L} \mathrm{pH} 10.4$ glycine buffer $(1: 1$ buffer: sample, by volume), fluorescence was measured at 455 $\mathrm{nm}$ under an excitation wavelength of $365 \mathrm{~nm}$. Activity was calculated as $\mu \mathrm{mol}$ substrate MUF per unit of time and biofilm surface area (see below for biofilm surface area measurements). PO and P activities were measured following the method described by Sinsabaugh et al. (1994). Incubations (1h) were performed at $1.5 \mathrm{mM}$ L-DOPA concentration with $\mathrm{pH} 5$ buffer acetate. Controls of each streambed substrata (without L-DOPA) and stream water (with and without L-DOPA) were performed. $\mathrm{P}$ activity was assayed in a similar manner but $0.2 \mathrm{ml}$ of $0.3 \% \mathrm{H}_{2} \mathrm{O}_{2}$ was added to controls and samples. $\mathrm{H}_{2} \mathrm{O}_{2}$ acts as an enzymatic cofactor for the $\mathrm{P}$ activity. After incubation, the optical density of the liquid phase at $460 \mathrm{~nm}$ was determined. Activity was calculated as mmol substrate DIQC (2,3dihydroindole-5,6-quinone-2-carboxilate) converted per $\mathrm{h}^{-1} \mathrm{~cm}^{-2}$ (see below for biofilm surface area measurements). Samples were also dried $\left(2\right.$ days at $\left.110^{\circ} \mathrm{C}\right)$ and burned $\left(4 \mathrm{~h}\right.$ in the oven at $\left.400^{\circ} \mathrm{C}\right)$ to obtain dry weight and ash-free dry weight (AFDW). The relationship between biofilm surface area, dry weight, and AFDW in each substrata was used for the transformations in the ergosterol measurements.

Biofilm surface area was calculated as the surface area in the substrata available for the microbial colonisation. The biofilm surface of sand was obtained after applying a conversion factor obtained by granulometry. In the gravel the biofilm surface area was obtained by measuring the surface of the paper used to wrap the grains. The biofilm surface area of leaves discs was $0.985 \mathrm{~cm}^{2}$ in each side of the disk. In branches, the biofilm surface area was obtained after calculating the surface of the whole cylinder.

The spatial distribution of benthic substrata at each sampling date was used to calculate the enzymatic activities in terms of streambed surface area in the reach. Measurements of $\mathrm{CBH}, \mathrm{PO}$ and $\mathrm{P}$ activities (mean values for each substrata and sampling date) were expressed per hour and for the whole reach.

\section{Fungal biomass}

The fungal biomass in leaves, branches, sand and gravel (3 replicates) was estimated by ergosterol content, an indicator of Eumycetes fungal biomass. The analysis was performed following Kominková et al. (2000). Frozen samples were lyophilized and subsamples from each substratum were placed in glass tubes. Extraction was performed with methanol at $80^{\circ} \mathrm{C}$ for $60 \mathrm{~min}$. The resultant extract was cleaned by solid-phase extraction (Gessner \& Schmitt 1996). Ergosterol was purified and quantified by high pressure performance liquid chromatography (HPLC) (Waters Inc.) configured as follows: solvent methanol; flow rate $0.7 \mathrm{ml} / \mathrm{min}$; column Licrospher $100 \mathrm{RP}-18$ (4.6 mm x $250 \mathrm{~mm}$ ); absorbance detector with a range from 210 $\mathrm{nm}$ to $400 \mathrm{~nm}$ at $1.2 \mathrm{~nm}$ resolution. Ergosterol was detected at $282 \mathrm{~nm}$ and quantification was based on the comparison with ergosterol standards (Fluka Chemical Co.). Results were expressed as $\mu \mathrm{g}$ ergosterol per $\mathrm{g}$ AFDM.

The fungal biomass per stream reach was obtained by multiplying the ergosterol content per area occupied by each substratum. Ergosterol per g AFDM (mean value for each substrata and sampling date) was transformed to ergosterol per $\mathrm{cm}^{2}$ biofilm by applying an empirical relationship between surface $\left(\mathrm{cm}^{2}\right)$ and $\mathrm{g}$ AFDM of the same substratum (see in Enzyme assays for the biofilm surface area calculations).

\section{Data analysis}

The differences between enzymatic activities and fungal biomass of the distinct streambed substrata over time were analysed using a two-way analysis of variance. A Multiple Comparison test (Scheffé) was used to observe the differences in activities between substrata. To detect the significance of the differences between organic and inorganic substrata, another ANOVA was performed after grouping leaves and branches versus sand and gravel, respectively. All variables were log transformed in order to assess the homogeneity of variances and the normal distribution of data before performing the ANOVA. Correlation analysis of environmental and biological variables was performed using the product-moment Pearson coefficient. The statistical analysis were carried out using SPSS for Windows (Ver. 12.0, SPSS Inc. 2003).

\section{Results}

\section{Physico-chemistry}

The physico-chemical parameters varied considerably during the study period. There was a progressive decrease in stream water temperature, which reached the lowest values in January 2003. Discharge increased up to 10 times the basal flow throughout the study period, producing drastic increases in inorganic nutrients (especially nitrate) and to a lesser extent in Dissolved Organic Carbon (Table 1). Discharge variations 
also caused changes in the proportions of benthic substrata during autumn (Table 2). The leaf material during the fall peak in October and November covered nearly $50 \%$ of the stream bed surface area. Accumulation of detritic material was inversely correlated with current values $(r=-0.904, p=0.005)$.

\section{Extracellular enzyme activities}

There were significant differences in $\mathrm{CBH}$ and $\mathrm{PO}$ activities between biofilms developed on different streambed substrata and throughout the study period (ANOVA, Table 3, Fig. 1). P activity showed significant differences among substrata but not over time (Table 3, Fig. 1). CBH activity was significantly higher in biofilms developed on organic substrata, while PO and $\mathrm{P}$ were significantly higher on those growing on inorganic substrata (Table 3). The highest CBH activities were detected on biofilm of decaying Populus nigra leaves (Scheffé test; Fig 1), followed by Alnus glutinosa, Platanus x hispanica and branches. The lowest $\mathrm{CBH}$ activity values were observed in biofilms of fresh leaves, sand and gravel substrata. Biofilm on sand and gravel showed the highest PO activity compared with that on organic substrata (Scheffé test; Fig 1). Among leaf species, the highest PO activity was measured in the biofilm on fresh and decaying leaves of $\mathrm{Al}$ - nus glutinosa while the lowest activity was on fresh Populus nigra leaves. The highest $\mathrm{P}$ activity was recorded in sand and gravel biofilm, even though there were not significant differences between different biofilms (Scheffé test; Fig 1). Among leaves, the highest $P$ activity was detected in biofilm on fresh and decaying Populus nigra leaves while the lowest was on fresh Platanus x hispanica leaves.

\section{Ergosterol content}

A general increase in fungal biomass occurred at the end of autumn in all the substrata analysed (Fig. 2). Ergosterol content showed differences over time and among substrata. Fungal biomass was higher on inorganic substrata, particularly on sand, than on leaves and branches (Table 3). Ergosterol on sand was ca. 10fold higher that on gravel. Among leaf species, Alnus glutinosa accounted for the highest fungal biomass.

\section{Stream reach capacity on OM decomposition}

The stream reach capacity for the different enzyme activities was calculated after considering the activities per the corresponding percent of substrata occupying the streambed. High values of $\mathrm{CBH}$ were characteristic of the whole study period. Both $\mathrm{PO}$ and $\mathrm{P}$ increased after several weeks (Fig 3). Biofilm in sand and gravel were responsible for the high values of PO

Table 1. Physical and chemical characteristics of the Fuirosos stream reach during the study period. Values for water nutrient content are means (3 replicates) and those for temperature and discharge are individual values of each of the seven sampling dates. Means and standard deviations (SD) for all the study period are also shown.

\begin{tabular}{lccccccccc}
\hline Date & $2-10$ & $16-10$ & $30-10$ & $13-11$ & $27-11$ & $17-12$ & $13-1$ & Mean & SD \\
& 2002 & 2002 & 2002 & 2002 & 2002 & 2002 & 2003 & & \\
\hline Temp $\left({ }^{\circ} \mathrm{C}\right)$ & 14.5 & 16.0 & 14.8 & 12.8 & 8.8 & 8.2 & 2.7 & 11.1 & 4.7 \\
Disch $(\mathrm{L} / \mathrm{s})$ & 8.3 & 30.6 & 21.4 & 19.6 & 87.6 & 47.1 & 28.2 & 34.7 & 26.2 \\
$\mathrm{NO}_{3}-\mathrm{N}(\mu \mathrm{g} / \mathrm{L})$ & 11.7 & 516.4 & 105.6 & 30.7 & 762.4 & 842.3 & 564.5 & 404.8 & 351.5 \\
$\mathrm{SRP}(\mu \mathrm{g} / \mathrm{L})$ & 2.5 & 12.6 & 4.6 & 3.6 & 12.6 & 14.6 & 3.9 & 7.8 & 5.2 \\
DOC $(\mathrm{mg} / \mathrm{L})$ & 2.6 & 4.9 & 4.1 & 3.6 & 4.4 & 1.5 & 3.3 & 3.5 & 1.1 \\
\hline
\end{tabular}

Table 2. Benthic description of the Fuirosos stream reach during autumn-winter 2002/03. Values are percent of each substratum occupying the streambed.

\begin{tabular}{|c|c|c|c|c|c|c|}
\hline \multirow[t]{2}{*}{ Sampling date } & \multicolumn{2}{|c|}{ Inorganic substrata } & \multicolumn{2}{|c|}{ Organic substrata } & \multirow[b]{2}{*}{$\begin{array}{l}\text { Fresh } \\
\text { leaves }\end{array}$} & \multirow[b]{2}{*}{$\begin{array}{l}\text { Detritic } \\
\text { material }\end{array}$} \\
\hline & Rock & Sand-gravel & Branches & $\begin{array}{l}\text { Decaying } \\
\text { leaves }\end{array}$ & & \\
\hline $2 / 10 / 02$ & 63.4 & 36.6 & 1.14 & 6.43 & 29.11 & 42.31 \\
\hline $16 / 10 / 02$ & 63.4 & 36.6 & 0.85 & 2.77 & 21.24 & 12.38 \\
\hline $30 / 10 / 02$ & 63.4 & 36.6 & 0.87 & 4.35 & 47.65 & 12.23 \\
\hline $13 / 11 / 02$ & 63.4 & 36.6 & 1.59 & 15.42 & 44.09 & 12.25 \\
\hline $27 / 11 / 02$ & 66.0 & 34.0 & 2.23 & 20.5 & 12.61 & 2.27 \\
\hline $17 / 12 / 02$ & 59.0 & 41.0 & 1.93 & 26.62 & 0.37 & 5.15 \\
\hline $13 / 01 / 03$ & 65.0 & 35.0 & 3.08 & 10.19 & No presence & 7.75 \\
\hline
\end{tabular}



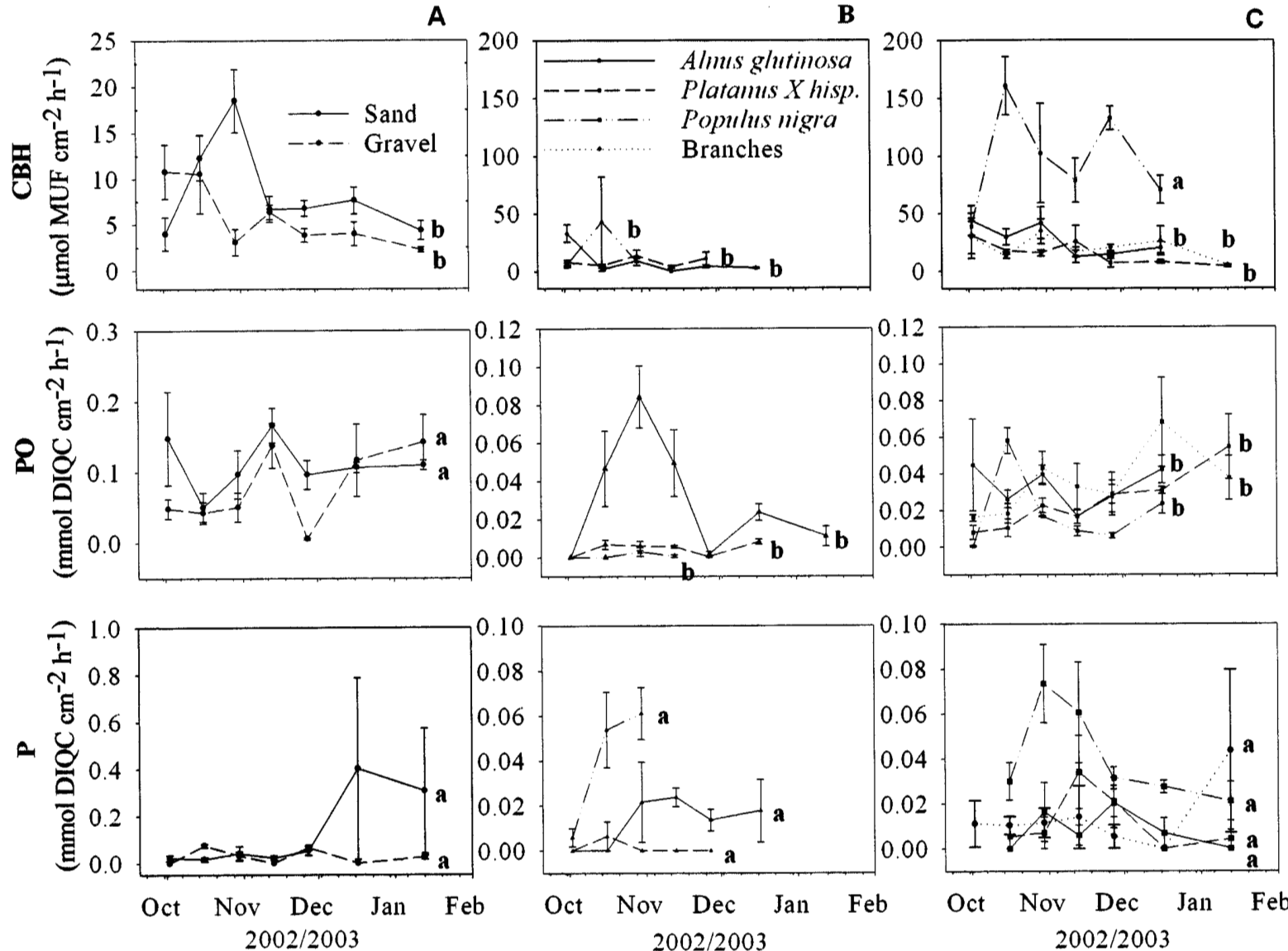

Fig 1. Enzymatic activities (CBH, PO and P) in (A) Sand and gravel, (B) fresh leaves, (C) decaying leaves and branches during 2002/2003 in Fuirosos stream. Values are means and SE of activity in each substrata (4 replicates) during the 7 sampling dates. Marked in small letter the groups with signifficant differences $(\mathbf{a}>\mathbf{b})$ obtained with the Scheffé test $(\alpha=0.05)$ are shown. Legend in graph B was also used in graph $\mathrm{C}$ where branches were represnted. (MUF= methylumbellyferone; DIQC=2,3-dihydroindole-5,6-quinone-2-carboxilate).

Table 3. Two-way analysis of variance performed between enzymatic activities of streambed substrata and over time (1), and grouping organic (leaves and branches) and inorganic (sand and gravel) substrata (2). F-statistics and probabilities for the different sources of variation and interactions are shown.

\begin{tabular}{lcccc}
\hline Sources & CBH & PO & $\mathrm{P}$ & Ergo \\
\hline (1) & & & & \\
Time & $F_{6,161}=6.43$ & $F_{6,162}=2.97$ & $F_{6,162}=1.08$ & $F_{6,71}=90.01$ \\
& $\mathrm{p}<0.0001$ & $\mathrm{p}<0.01$ & $\mathrm{~ns}$ & $\mathrm{p}<0.0001$ \\
Substrata & $F_{8,161}=37.65$ & $F_{8,162}=23.18$ & $F_{8,162}=2.61$ & $F_{8,71}=5.64$ \\
& $\mathrm{p}<0.0001$ & $\mathrm{p}<0.0001$ & $\mathrm{p}<0.05$ & $\mathrm{p}<0.0001$ \\
Time x Substrata & $F_{39,161}=2.55$ & $F_{39,162}=2.78$ & $F_{39,162}=0.93$ & $F_{36,71}=2.23$ \\
& $\mathrm{p}<0.0001$ & $\mathrm{p}<0.0001$ & $\mathrm{~ns}$ & $\mathrm{P}<0.005$ \\
$(2)$ & & & & \\
Time & $F_{6,201}=1.67$ & $F_{6,202}=6.16$ & $F_{6,202}=1.74$ & $F_{6,108}=53.71$ \\
& $\mathrm{~ns}$ & $\mathrm{p}<0.0001$ & $\mathrm{~ns}$ & $\mathrm{p}<0.0001$ \\
Substrata & $F_{1,201}=12.37$ & $F_{1,202}=124.65$ & $F_{1,202}=10.36$ & $F_{1,108}=18.43$ \\
& $\mathrm{p}<0.005$ & $\mathrm{p}<0.0001$ & $\mathrm{p}<0.005$ & $\mathrm{p}<0.0001$ \\
Time x Substrata & $F_{6,201}=0.49$ & $F_{6,202}=6.52$ & $F_{6,202}=1.94$ & $F_{6,108}=4.27$ \\
& $\mathrm{~ns}$ & $\mathrm{p}<0.0001$ & $\mathrm{~ns}$ & $\mathrm{p}<0.005$ \\
\hline
\end{tabular}


and $\mathrm{P}$ activities. $\mathrm{CBH}$ showed higher values in biofilms on organic substrata, being initially higher on fresh leaves and later increasing on decaying leaves. Water temperature was negatively correlated with the PO activity in biofilms on decaying leaves and branches, but positively correlated with the $\mathrm{CBH}$ activity in sand-gravel biofilms (Table 4). Dissolved inorganic nitrogen $(\mathrm{DIN}=$ nitrate+nitrite+ammonia) was positively correlated with PO in biofilm on decaying leaves and $\mathrm{P}$ in biofilm on sand-gravel (Table 4).

A

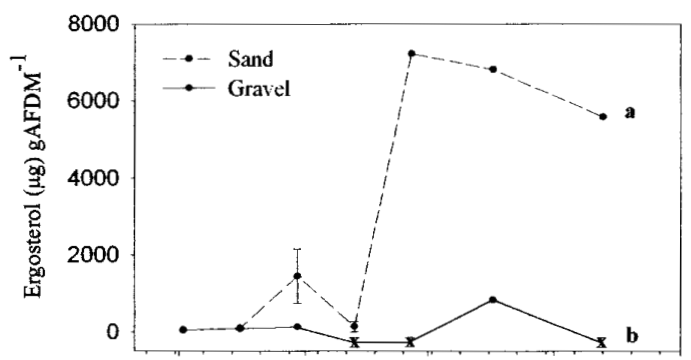

B

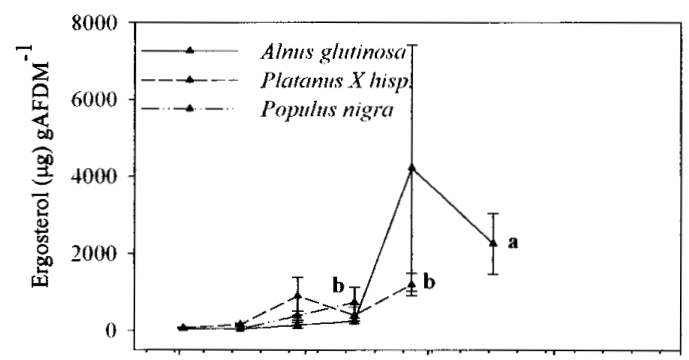

C



Fig 2. Ergosterol content on the streambed substrata during autumnwinter 2002/03 in Fuirosos stream: (A) Sand and gravel, (B) fresh leaves, (C) decaying leaves and branches. Values are means and SE of ergosterol in each substrata (3 replicates) during the 7 sampling dates. Marked in small letter the groups with signifficant differences $(\mathbf{a}>\mathbf{b})$ obtained with the Scheffé test $(\alpha=0.05)$ are shown. (x) indicate samples under detection limit of the ergosterol content method used (aprox. $0.2517 \mu \mathrm{g}$ ergosterol gAFDM-1). Some samples have no SE since the lack of replicates.
Maximum fungal biomass was reached in November and December. Ergosterol was first accumulated on fresh and decaying leaves (November) but later on was more abundant on sand-gravel (Fig 4). Lignocellulosic activities were correlated with the ergosterol content of decaying leaves and branches (PO activity) and sandgravel substrata (P activity) (Table 4). The peroxidase activity in the reach (obtained as the integration of the enzymatic activity values in each substrata) was significantly correlated with DIN ( $r=0.964, \mathrm{p}<0.0001)$. Integrated fungal biomass per stream reach was also correlated with DIN $(r=0.770, \mathrm{p}<0.0001)$.
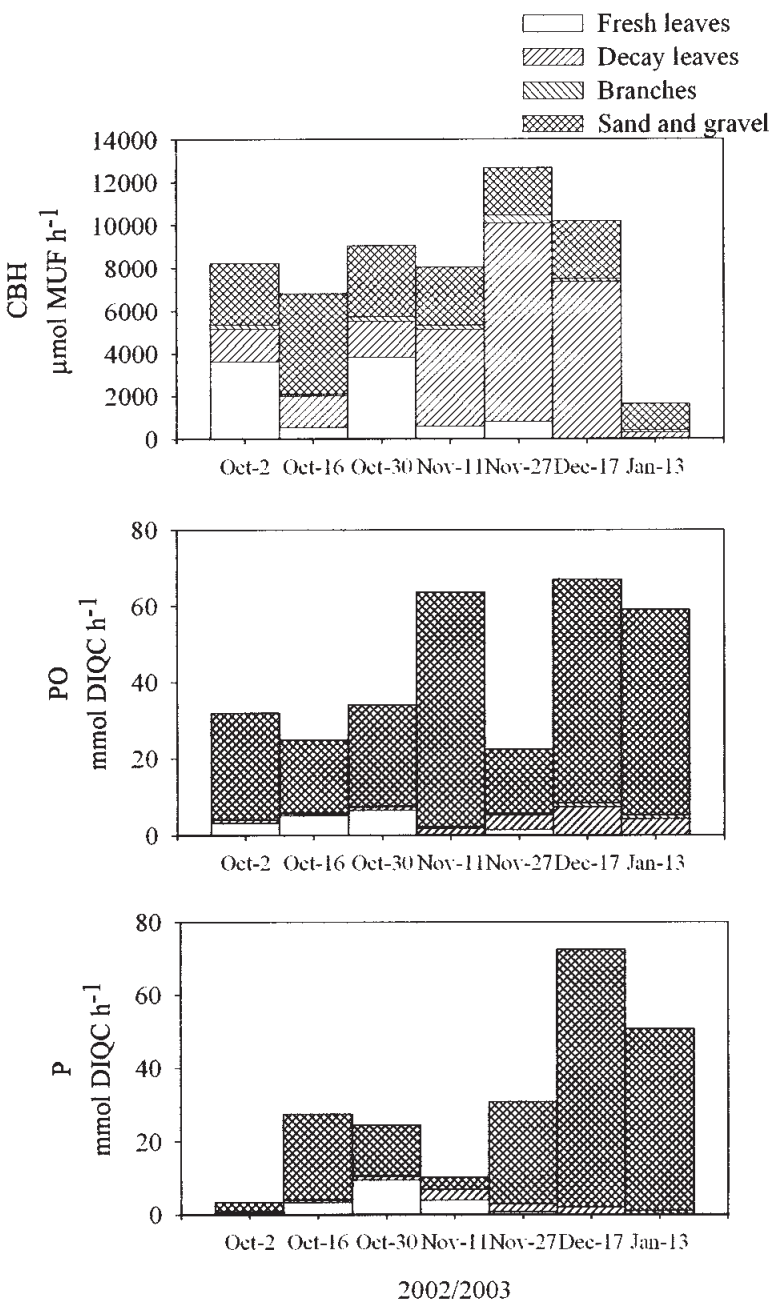

Fig 3. Enzymatic activity values corrected by real surface area occupied by each substratum in the studied stream reach. Units are $\mu$ mol MUF (CBH) and mmol DIQC (PO and $\mathrm{P}$ ) $\mathrm{h}^{-1}$ in the whole reach. 


\section{Discussion}

Organic matter decomposition showed a clear temporal pattern and remarkable differences in the enzymatic activities and ergosterol content between substrata. According to the model of Berg (1986), the decomposition of fresh leaves begins with the easily mineralised fractions of non-lignified carbohydrates, whereas later stages are characterized by mineralization of more recalcitrant fractions of lignified carbohydrates. In the Fuirosos stream after leaf fall peak (October), CBH activity was high for the whole period, while $\mathrm{P}$ and $\mathrm{PO}$ activities increased only after several weeks. This observation indicates that OM decomposition began with cellulose decomposition followed by

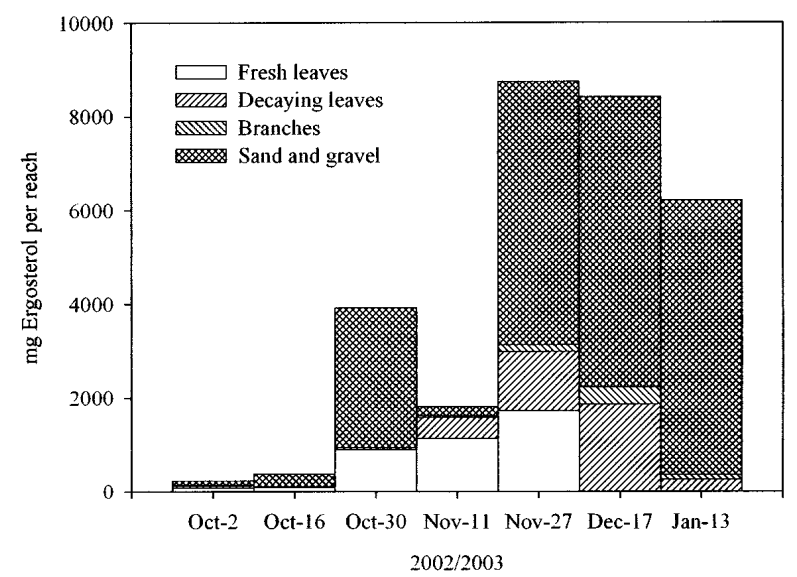

Fig. 4. Ergosterol content corrected by real surface area occupied by each substratum in the studied stream reach. Units are mg ergosterol in the whole reach. degradation of lignin compounds. However, physicochemical parameters, such as discharge and DIN, may also determine the time-pattern of the enzymatic activity. The abrupt flows in autumn or early winter in Mediterranean streams (Gasith \& Resh 1999) may mobilise most of the nitrate in the catchment of the Fuirosos stream (Bernal et al. 2002). After the dry period (summer) the first storms caused the weathering of dissolved and particulate $\mathrm{OM}$ accumulated on soil, and $\mathrm{N}$ concentration in streamwater was positively correlated with lignocellulosic activities ( $\mathrm{P}$ and $\mathrm{PO}$ ). Therefore fungal activities were enhanced by nitrate availability in a system where $\mathrm{N}$ may be a limiting resource (Romaní et al. 2004). An enhancement of lignocellulosic activities by the water $\mathrm{N}$ content has been observed in other systems (Alvarez \& Guerrero 2000). However, Carreiro et al. (2000) described the inhibition of these activities by high $\mathrm{N}$ concentrations.

Differences between biofilms colonising organic or inorganic substrata were evident in Fuirosos. Lignocellulosic activities were higher on inorganic substrata biofilm (developed over sand and gravel) while CBH was higher in biofilm developed on organic substrata (leaves and branches). High ligninolytic activities in sand and gravel biofilm were caused by the large accumulation of detritic material derived from decomposing terrestrial litter. The largest accumulation of this material occurred in the slow-moving habitats, coinciding with stream pools or littoral zones where sand and gravel were the main substrata. The fine detritus accumulated in these substrata might be composed by a higher proportion of lignin (Yeager \& Sinsabaugh 1998, Sinsabaugh \& Findlay 1995). The lower CBH activity

Table 4. Correlations (Pearson coefficients) calculated for $\mathrm{CBH}, \mathrm{PO}$ and $\mathrm{P}$ activities in terms of surface occupied by each substratum on the streambed and physico-chemical variables (discharge, temperature, dissolved inorganic nitrogen $(\mathrm{DIN}=$ nitrate + nitrite + ammonia) and dissolved inorganic carbon (DIC)). Streambed substrata are indicated FL (fresh leaves), DL (decaying leaves), B (branches), and S-G (sand and gravel). Substrata and physico-chemical variables with any significant correlation are not included in the table. Level of significance is indicated by asterisks: $* \mathrm{p}<0.05$ and $* *$ $\mathrm{p}<0.001$.

\begin{tabular}{ccccccccc}
\hline Activ & Substr & Temp & Disch & DIN & DIC & CBH & PO & P \\
\hline CBH & DL & ns & $0.823^{*}$ & ns & ns & 1 & ns & ns \\
& S-G & $0.89^{* *}$ & ns & ns & ns & 1 & ns & ns \\
PO & FL & $0.76^{*}$ & ns & ns & ns & ns & 1 & ns \\
& DL & $-0.76^{*}$ & ns & $0.76^{*}$ & ns & ns & 1 & ns \\
& B & $-0.86^{*}$ & ns & ns & $-0.93^{*}$ & ns & 1 & ns \\
P & S-G & ns & $0.82^{*}$ & $0.96^{* *}$ & $-0.96^{* *}$ & ns & ns & 1 \\
Ergost. & DL & ns & ns & ns & ns & $0.88^{*}$ & $0.87^{*}$ & ns \\
& B & ns & ns & ns & $-0.80^{*}$ & ns & $0.88^{*}$ & ns \\
& S-G & $-0.82^{*}$ & ns & $0.76^{*}$ & $-0.91^{*}$ & ns & ns & $0.82^{*}$ \\
\hline
\end{tabular}


of biofilm growing on sand and gravel indicates the low availability of cellulose compounds on detritus particles. In contrast, high $\mathrm{CBH}$ activity in biofilms developed on organic substrata could reflect the availability of cellulolytic compounds on leaves and branches.

The enzymatic activities of biofilms differed on the leaves of different species, which might be attributable to differences in leaf composition $(\mathrm{C}: \mathrm{N}$ ratio, lignin content, polyphenol content, leaf durability ; Griffin 1994). The lower enzymatic activities for the biofilm on Platanus x hispanica was already observed in previous studies developed on leaf decomposition in soil and in other aquatic habitats. The high $\mathrm{C}: \mathrm{N}$ ratio measured in this substratum (Bernal et al. 2003, Ostrofsky 1997) may be pointed out as the cause for the low mineralisation observed for this material. Slower breakdown of Platanus leaves than other indigenous Mediterranean leaf species (e. g: Populus nigra) (Casas \& Gessner 1999) is probably caused by the higher lignin and other recalcitrant compounds content in the former (Ostrofsky 1997). In contrast, high CBH and P activities were recorded in biofilms on Populus nigra leaves, while the highest PO was measured on Alnus glutinosa biofilm. Differences in PO activities between biofilms of leaf material of these two tree species are probably related to the inhibition effect of phenolic compounds (Pind et al. 1994). The lower polyphenol content in Alnus glutinosa than in Populus nigra leaves (Pereira et al. 1998) may imply a higher PO activity. This distinct enzymatic behaviour determines a faster decomposition of Alnus glutinosa leaves in the stream reach, followed by those of Populus nigra and finally by Platanus x hispanica.

Fungal biomass was generally related with the enzymatic activities measured in the different substrata, indicating that fungi were responsible for most of decomposition processes that occurred in the stream in autumn (Griffin 1994). The similar PO activity values measured in biofilm in sand and gravel substrata, but the lower fungal biomass in gravel, may be related to a higher proportion of fungi with PO ability (white rot fungi, Dix \& Webster 1995) on gravel than on sand. However, this activity in gravel could also be produced by some microorganisms (e. g: bacteria) using at least part of the degradation intermediates of lignin generated by fungi (Rüttimann et al. 1991). This possibility was supported by Baldy et al. (1995), who showed the importance of bacteria in the late stages of the breakdown process of leaves.

The estimates of ergosterol concentration per stream reach showed a progression of fungal biomass throughout the study period, which decreased only after most of the material had been processed. Fungi could be considered as facultative microorganisms in the sense of selection and colonization of riverbed substrata during the fall. They used the new allochthonous substrata (leaves) that entered the system during autumn. When leaf material was carried downstream, the fungi remained active on the particulate OM derived from the breakdown of leaves and branch material, therefore achieving complete decomposition of all the material that entered the reach during this season.

\section{Acknowledgements}

This study was funded by the Spanish Ministry of Science and Technology (REN 2002-04442-C02-02).

\section{References}

Alvarez S. \& Guerrero M.C. 2000. - Enzymatic activities with decomposition of particulate organic matter in two shallow ponds. Soil Biol. Biochem., 32, 1941-1951.

APHA 1989. - Standard Methods for the examination of water and wastewater, $17^{\text {th }}$ Ed. American Public Health Association, Washington, $1134 \mathrm{pp}$.

Baldy V., Gessner M. O. \& Chauvet E. 1995. - Bacteria, fungi and the breakdown of leaf litter in a large river. Oikos, 74, 93-102.

Bärlocher F., Canhoto C. \& Graça M. A. S. 1995.- Fungal colonization of alder and eucalypt leaves in two streams in central Portugal. Arch. Hydrobiol., 133, 57-68.

Berg B. 1986. - Nutrient release from litter and humus in coniferous forest soils: a mini review. Scand. J. For. Res., 1, 359-369.

Bernal S., Butturini A., Nin E., Sabater F \& Sabater, S. 2003. - Leaf litter dynamics and nitrous oxide emission in a Mediterranean riparian forest: implications for soil nitrogen dynamics. J. Environ. Qual., 32, 191-197.

Bernal S., Butturini A. \& Sabater F. 2002. - Variability of DOC and nitrate responses to storms in a small Mediterranean forested catchment. Hydrol. Earth Syst. Sci., 6, 1031-1041.

Carreiro M. M., Sinsabaugh R. L., Repert D. A. \& Parkhurst D. F. 2000. - Microbial enzyme shifts explain litter decay responses to simulated nitrogen deposition. Ecology, 8, 2359-2365.

Casas J. J. \& Gessner M. O. 1999. - Leaf litter breakdown in a Mediterranean stream characterised by travertine precipitation. Freshwater Biol., 41, 781-793.

Diez J., Elosegi A., Chauvet E. \& Pozo J. 2002. - Breakdown of wood in the Aguera stream. Freshwater Biol., 47, 2205-2215.

Dix N. \& Webster J. 1995. - Fungal Ecology. Chapman \& Hall, New York, USA, 397pp.

Findlay S.E.G. \& Arsuffi T. L. 1989. - Microbial growth and detritus transformation during decomposition of leaf litter in the stream. Freshwater Biol., 21, 261-269.

Fisher S.G. \& Likens G.E. 1973. - Energy flow in Bear Brook, New Hampshire: an integrative approach to stream ecosystem metabolism. Ecol. Monogr., 43, 1632-1640.

Gasith A. \& Resh V.H. 1999. - Streams in Mediterranean climate regions: abiotic influences and biotic responses to predictable seasonal events. Ann. Rev. Ecol. Syst., 30, 51-81.

Gessner O.M. \& Chauvet E. 1994. - Importance of stream microfungi in controlling breakdown rates of leaf litter. Ecology, 75,18071817.

Gessner O.M. \& Schmitt A. L. 1996. - Use of solid-phase extraction to determine ergosterol concentrations in plant tissue colonized by fungi. Appl. Environ. Microbiol., 62, 415-419.

Griffin D. H. 1994. - Fungal Physiology. Ed. Wiley-Liss, $2^{\text {nd }}$ edition, New York, 485pp. 
Hieber M. \& Gessner M. O. 2002. -Contribution of stream detritivores, fungi, and bacteria to leaf breakdown based on biomass estimates. Ecology, 83, 1026-1038.

Komínková D., Kuehn K.A., Büsing N., Steiner D. \& Gessner M.O. 2000. - Microbial biomass, growth, and respiration associated with submerged litter of Phragmites australis decomposing in a littoral reed stand of a large lake. Aquat. Microb. Ecol., 22, 271-282.

Mathuriau C. \& Chauvet E. 2002. -Breakdown of leaf litter in a neotropical stream. J. N. Am. Benthol. Soc., 21, 384-396.

Minshall G.W., Petersen R.C., Cummins K.W., Bott T.L., Sedell J.R., Cushing C.E. \& Vannote R.L. 1983. - Interbiome comparison of stream ecosystem dynamics. Ecol. Monogr., 53, 1-25.

Ostrofsky M. L. 1997. - Relationship between chemical characteristics of autumn-shed leaves and aquatic processing rates. J. N. Am. Benthol. Soc., 16, 750-759.

Pereira A.P., Graça M.A.S. \& Molles M. 1998. - Leaf litter decomposition in relation to litter physico-chemical properties, fungal biomass, arthropod colonization, and geographical origin of plant species. Pedobiologia, 42, 316-327.

Pind A., Freeman C. \& Lock M.A. 1994. - Enzymic degradation of phenolic materials in peatlands- measurement of phenol oxidase activity. Plant Soil., 159, 227-231.

Pozo J., Basaguren A., Elósegui A., Molinero J., Fabre E. \& Chauvet E. 1998. - Afforestation with Eucaliptus globulus and leaf litter decomposition in streams of northern Spain. Hydrobiologia, 373-374, 101-109.

Romaní A.M., Giorgi A., Acuña V. \& Sabater S. 2004. -The influence of substratum type and nutrient supply on biofilm organic matter utilization in streams. Limnol. Oceanogr., 49, 1713-1721.
Rüttimann C., Vicuña R., Mozuch M.D. \& Kirk T.K. 1991. - Limited bacterial mineralization of fungal degradation intermediates from synthetic lignin. Appl. Env. Microbiol., 3652-3655.

Sabater S., Bernal S., Butturini A., Nin E. \& Sabater F. 2001. - Wood and leaf debris input in a Mediterranean stream: the influence of the riparian vegetation. Arch. Hydrobiol., 153, 91-102.

Sinsabaugh R.L. \& Fidnlay, S. 1995. - Microbial production, enzyme activity, and carbon turnover in surface sediments of the Hudson river estuary. Microb. Ecol., 30, 127-141.

Sinsabaugh R.L., Osgood M.P. \& Findlay S. 1994. - Enzymatic models for estimating decomposition rates of particulate detritus. $J$. N. Am. Benthol. Soc., 13, 160-169.

Sinsabaugh R.L., Antibus R.K. Linkins A.E. McClaugherty C.A., Raybun L., Repert D. \& Weiland T. 1992. - Wood decomposition over a first order watershed: mass loss as a function of lignocellulase activity. Soil Biol. Biochem., 24, 743-749.

Suberkropp K. 1995. - The influence of nutrients on fungal growth, productivity, and sporulation during leaf breakdown in streams. Can. J. Bot., 73, S1361-S1369.

Suberkropp K. \& Klug M.J. 1976. - Fungi and bacteria associated with leaves during processing in a woodland stream. Ecology, 57 , 707-719.

Yeager P.E. \& Sinsabaugh R.L. 1998. - Microbial diversity along a sediment detrital particle size gradient. Aquat. Ecol., 32, 281-289. 